https://doi.org/10.31470/2706-7904-2020-15-49-53

\title{
ПСИХОЛІНГВІСТИЧНА СТРУКТУРА ВЕРБАЛІЗОВАНОГО КОНЦЕПТУ «ФЛІРТ»
}

The Psycholinguistic Structure of the Concept of «Flirting»

\section{Iia Gordiienko-Mytrofanova}

DSc. in Psychology, Professor

H.S. Skovoroda Kharkiv National Pedagogical University (Ukraine)

ikavgm@gmail.com

https://orcid.org/0000-0001-5332-0663

\section{Iuliia Kobzieva}

MA in Psychology

H.S. Skovoroda Kharkiv National Pedagogical University (Ukraine)

yu.kobzeva88@gmail.com

https://orcid.org/0000-0001-8483-9695

\section{Serhii Sauta}

MA in Psychology

H.S. Skovoroda Kharkiv National Pedagogical University (Ukraine)

sergeisauta@gmail.com

https://orcid.org/0000-0002-1213-2655

\begin{abstract}
The aim of this study was to reveal and to describe the structure of the verbalized concept of "flirting». The main method of the research was a psycholinguistic experiment. The sample comprised 400 young people (aged 18-35), males and females being equally represented. The concept of "flirting» is represented by eleven clusters, four of them are core: "verbal and nonverbal ways of communication», "forms and ways of interaction», "emotions, feelings, states», and "gender». Two psycholinguistic meanings of "flirting» concept were described: "The stage of courtship with no intimate relation», "Sexual relationship». The semantic content of the concept of "flirting» does not depend on gender identification. The general attitude of the respondents to the stimulus «lightness» is quite positive.
\end{abstract}

Key words: ludic competence, playfulness, ludic position, flirting, psycholinguistic experiment, free association test, linguistic consciousness, youth. 


\section{Ветуп}

Introduction

Ігрова компетентність визначається нами як система внутрішніх ресурсів, до якої звертається людина 3 метою найкращого врівноважування своєї індивідуальності з зовнішніми умовами соціального оточення на основі позитивних емоцій - інтересу й радості, часто їх афективного прояву, що супроводжується напруженням або збудженням.

Формування ігрової компетентності передбачає розвиток грайливості як стійкої особистісної властивості (stable personality trait), яка виявляє себе як творча адаптація особистості до реальності свого «Я» (індивідуальна ідентичність) і до реальності Світу (соціальна ідентичність), що дозволяє сприймати складні ситуації не як загрозу, а як виклик.

Ми вивчаємо грайливість/ігрову компетентність із позиції психолінгвістичного підходу. За допомогою психолінгвістичного експерименту було верифіковано компоненти грайливості/ігрової компетентності й відповідні до них ігрові позиції: сензитивність - Емпат; гумор - Справжній гуморист; легкість - Еквілібрист; уява - Скульптор; флірт - Дипломат; пустотливість - Пустун; ф'юг - Юродивий (Gordienko-Mytrofanova \& Sauta, 2016; Gordienko-Mytrofanova \& Kobzieva, 2017; Gordiienko-Mytrofanova et al., 2020a, 2020b).

Групове дослідження (2016-2020 гг.) фолірту як компонента ігрової компетентності / грайливості проводилося Ю. Кобзєвою, К. Куликовською, C. Саутою, Є. Бумар під керівництвом I. Гордієнко-Митрофанової на кафедрі психології Харківського національного педагогічного університету імені Г.С. Сковороди.

Метою прикладного психолінгвістичного дослідження було виявлення психолінгвістичної структури вербалізованого концепту «флірт», через опис іiі семантичних компонентів у мовній свідомості російськомовних жителів України молодого віку.

\section{Методи та методики дослідження} Methods and Techniques of the Research

Методом проведеного дослідження став психолінгвістичний експеримент, головним етапом якого $\epsilon$ вільний асоціативний експеримент (ВАЕ) зі словом-стимулом «флірт». Загальна кількість випробовуваних, які взяли участь в експерименті, становила 400 осіб молодого віку (18-35 років) у рівному співвідношенні чоловіків і жінок. Із них за 
критерієм «освіта» 24\% респондентів мають незакінчену вищу освіту (студенти), 58\% вищу освіту, 18\% - середню освіту; за критерієм «сімейний стан» 24\% - перебувають у зареєстрованому цивільному шлюбі, 76\% - не перебувають у шлюбі.

\section{Результати}

\section{Results}

Підсумком проведеного дослідження було розподілення 400 реакцій за семантичним групами/кластерами й опис психолінгвістичних значень. Проведений кластерний аналіз показав, що ядро вербалізованого концепту «флірт» репрезентується чотирма семантичними групами, які представлені у відносно рівному співвідношенні чоловічих та жіночих реакцій: «вербальні та невербальні засоби спілкування» (27.75\%), «форми й види взаємодї̈ (25.25\%), «емоції, почуття, стани» (24.75\%) і «стать» (10.5\%). Отже, вербалізований концепт «флірт» репрезентується лексемами, що відображають переважно невербальну комунікацію (посмішка, погляд, поцілунок, дотики), форми і види взаємодії (гра, зустріч, побачення), лексемами, які виражають почуття й емоції (любов, симпатія, інтерес, потяг), а також лексемами, що репрезентують жіночу стать (дівчина, жінка, дама, кокетка).

В асоціативній поведінці як чоловіків, так i жінок флірт пов'язаний iз «невербальними засобами спілкування» (10.5\% жін./10.25\% чол.). Однак підкластер «вербальні засоби спілкування» представлений переважно чоловічими реакціями (5.5\% чол. / $1.5 \%$ жін.).

I чоловіки, i жінки пов'язують флірт із «діяльністю зі зваблення», але периферійний підкластер «статеві стосунки» характеризується переважанням чоловічих реакцій (3\% чол./1.5\% жін.).

Асоціативну поведінку респондентів характеризує також гетеросексуальна орієнтація флірту, що й відображено в підкластері «гетеросексуальність», а також у тому, що чоловіки пов'язують флірт із жіночою статтю (5.75\% чол. / 1.75\% жін.), а жінки, відповідно, - із чоловічою (1.5\% жін. / 0.25\% чол.).

Периферійні кластери (менші 10\%, але більші за 1\%) «романтичні стосунки» (4\%) i «місие зустрічі» (1.5\%) представлені відносно однаковою кількістю чоловічих і жіночих реакцій. Кластери крайньої периферії, представлені винятково жіночими (приховані діi) або виключно чоловічими реакціями (пора року), свідчать швидше про певний ступінь індивідуальних уподобань слововживань на стимул «флірт», ніж про статеводетерміновані реакції. Аналіз одиничних реакцій дозволив виділити такі семантичні групи-реакції: вік (молодість), «період часу» (тимчасовість) і «час доби» (пізнішає).

Реакції-синонімом: кокетування 13, залицяяня 4 - 17 (4.25\%), жін. 11 (2.75\%), 
чол. 6 (1.5\%). Відлуння-реакція: фліска - 1 (0,25\%), чол. 1 (0.25\%). Неінтерпретовані реакції: флінт - $1(0.25 \%)$, чол. $1(0.25 \%)$.

Із урахуванням результатів кластерного аналізу були описані два психолінгвістичних значення слова-стимулу «флірт»: (1). Різновид залицяння, не допускає сексуальної близькості (сукупний індекс яскравості значення - 360 (90\%)); кть слів - 83; словосполучень - 11) і (2). Статеві стосунки (сукупний індекс яскравості значення - 18 (4.5\%); к-ть слів - 4).

Спираючись на результати аналізу реакцій із негативною конотацією, можна стверджувати, що ставлення інформантів до стимулу «флірт» емоційно-позитивне та характеризується позитивним його оцінюванням.

Аналіз асоціативного поля стимулу «флірт» дозволив також виявити невелику кількість реакцій із негативною конотацією (2\%). До них належать такі поодинокі реакції: зрада 3, альфонс, легковажність, лестощі, зваблення, пікап 1.

\section{Висновки \\ Conclusions}

Психолінгвістична структура вербалізованого концепту «флірт» представлена одинадцятьма кластерами, із яких чотири ядерних кластери (більше 10\%): «вербальні та невербальні засоби спілкування» (27.75\%), «форми та види взаємодії》 (25.25\%), «емочії, почуття, стани» (24.75\%) і «стать» (10.5\%); два периферійних (менше 10\%, але більше за 1\%): «романтичні стосунки» (4\%) і «місие зустрічі» (1.5\%); два кластери крайньої периферії (не більше $1 \%$, але менше за 0.25\%): «пора року» (0.5\%), «приховані діï» (0.5\%); три одиничних кластери-реакції: «вік», «час доби», «період часу».

За результатами кластерного аналізу описано два психолінгвістичних значення стимулу «флірт»: (1). Різновид залицяння, який не допускає сексуальної близькості, i (2). Статеві стосунки. Психолінгвістичні значення дозволили розкрити семантику концепту «флірт» як одиницю психологічно реальної мовної свідомості російськомовних жителів України молодого віку, включаючи велику семантичну периферію значень, а також семантичні компоненти лінгвокультурологічного характеру, які не виявляються за допомогою традиційних методів семантичного аналізу (Sternin \& Rudakova, 2011: 188).

Так, наприклад, семантичні компоненти лінгвокультурологічного характеру відображені в підкластері «гетеросексуальність». Аналіз отриманих результатів також показав, що флірт і секс у мовній свідомості російськомовних жителів України не утворюють нерозривної єдності. Сексуальний мотив флірту втілився в периферійних семантичних підгрупах «статеві стосунки» (4.5\%) і «діяльність зі зваблення» (1.5\%). 
Семантичне наповнення ядра концепту «флірт» не залежить від статевої ідентифікації. Ставлення інформантів до стимулу «флірт» характеризується позитивним його оцінюванням, а спираючись на результати аналізу реакцій із негативною конотацією, можемо визначити його як емоційно-позитивне.

\section{Література}

References

Стернин, И.А., \& Рудакова, А.В. (2011). Психолингвистическое значение слова и его описание. Воронеж: Ламберт.

Gordienko-Mytrofanova, I., \& Sauta, S. (2016). Playfulness as a peculiar expression of sexual relationships (semantic interpretation of the results of the psycholinguistic experiment). European Humanities Studies: State and Society, 1, 46-62. ehs-ss.pl/czasopismo/EHS-SS-01-2016.pdf

Gordienko-Mytrofanova, I., \& Kobzieva, Iu. (2017). Playful competence: the access code to the inner resources. Proceedings of the $15^{\text {th }}$ European Congress of Psychology, July 11-14, 2017 (p. 19). Amsterdam, Netherlands.

Gordiienko-Mytrofanova, I., Kobzieva, I., \& Borokh, K. (2020a). Investigating the concept of "lightness" as reflected in the Russian-speaking Ukrainians' linguistic consciousness. East $\begin{array}{lllll}\text { European Journal of } & \text { Psycholinguistics, }\end{array}$ https://doi.org/10.29038/eejpl.2020.7.1.gor

Kobzieva, Iu., Gordiienko-Mytrofanova, I., Udovenko, M., \& Sauta, S. (2020b). Concept "humour" in the linguistic consciousness of the Russian-speaking population of Ukraine. European $\begin{array}{lllll}\text { Journal of Humour } & \text { 29-44. }\end{array}$ http://dx.doi.org/10.7592/EJHR2020.8.1.kobzieva 